\title{
Implementation of Assessment for Learning and The Need for Teachers Refreshing Trainings
}

\author{
Dr. Shahzadi Seema, Lecturer, Department of Education, The University of Haripur, \\ shahzadiseema29@gmail.com \\ Dr. Wilayat Bibi, Assistant Professor, Department of Education, Shaheed Benazir Bhutto Women University \\ Peshawar,wkhan104@gmail.com \\ Dr. Waqar Un Nisa Faizi, Assistant Professor, Department of Education, Islamia College Peshawar, KP, \\ Pakistan,waqarnasir617@gmail.com
}

\begin{abstract}
A consistent continuing professional development is requisite to equip teachers with the indispensable proficiencies for their new roles as well as to keep them up to date in their job market. In this context, current study investigated the perceptions of teachers regarding the need for refreshing trainings in developing their skills for the implementation of assessment for learning at undergraduate program in public sector universities of Khyber Pakhtunkhwa. The sample comprised of randomly selected 40 teachers, 8 teachers, each of five public sector universities in Khyber Pakhtunkhwa. To get the relevant data, semi-structured interview schedules were used and was analyzed by adopting a thematic approach. Teachers strongly signified the expanded professional development opportunities instead of relying on conventional programs. Teachers stressed that to be provided with opportunities to improve their assessment skills by doing away with customary assessment methodologies while, embracing new advanced student-centered teaching and assessment approaches. The respondents were of the view that though they have command on subject matter and also have skills of teaching but to cope with new teaching learning practices they feel the need to be equipped with essential innovative skills as the more they get the opportunities to participate in refreshing trainings and do implement such assessment strategies in real classroom environments, the more they will be in a position to comprehend the productive worth of the assessment practices on students learning.
\end{abstract}

Keywords: Teachers Refreshing Trainings, Implementation of Assessment for Learning, Under-Graduate Program, KP Universities.

Received: 04.12.2020 Accepted: 18.01.2021 $\quad$ Published: 04.02.2021

\section{INTRODUCTION}

For researchers the efficacy of a teacher in multidimensional classroom circumstances has always been an area of high concern. Subject matter the expertise merely in subject matter is not the criteria that the competent teacher has to accomplish. It is an actual challenge for teachers to emphasis on creating a conducive environment in the classroom where redesigning and reshaping of knowledge, motivation, intellectual inquisitiveness, appropriate assessment of over-all development and independent and innovative thinking can occur conveniently. To inculcate these characteristics in teachers, teacher training programs, whether in the form of pre-service or in-service place vital stress on developing skills and their competencies among teachers (Guskey, 2000).

Dudley-Marling, et al (2006) quoted that in any educational program the teacher is the most vital constituent. It is the teacher who is chiefly responsible for implementation of the educational process at any phase. This illustrates that it is indispensable to invest in the development of teachers, in order to secure the future of a nation.

Like other teaching activities, teachers also perform assessment practices. It is estimated that teachers devote up to 50 percent of their time on the activities which are assessment-related (Plake, 1993). Irrespective of the extent of time spent on assessment practices, classroom assessment is an enormously imperative teaching role, contributing to the role of every other teacher (Brookhart, 1999b). Assessment can be used for several purposes: to identify the needs of students, to classify and grade students, to assess the instruction process, to stimulate students for learning and the most of all to facilitate learning (Stiggins, 1999a). Comprehensive assessment practices support teachers to improve their instructional procedures, progress students' motivation to learn, and upsurge students' levels of achievement (Brookhart, 1999a). 
Scheurich, Skrla and Johnson (2000) highlighted on assessment and the use of a number of assessment procedures, numeral constructive effects have been reported, e.g. there is a growth of students in their academic tracks as well as skills based on certain period when test scores were equated to those which did not take such opportunities. Similarly, the achievement of institutes and progress has been seen which provides promising reasons for modifications of assessment and the implementation of a range of assessment practices for improving learning (Beaton et al. 1999).

According to Race, Brown, and Smith, (2004) the assessment has a noteworthy outcome on the ways of students' learning and their learning and it is the selection of assessment strategies made by the classroom teachers which scrutinized the progression of students learning. As teachers are principally responsible for mediating the learning process and evaluating instruction and student learning, there is a pervasive concern about the eminence of classroom assessment and the professional development of teachers. Literature on classroom assessment has explained the content domain in which teachers need to develop assessment skills for to its use of different purposes (Airasian, 1994; Carey, 1994; and Stiggins, 1997).

\section{Significance of Refreshing Trainings}

Teacher preparation is allied to student success, yet commonly, teachers are entering the profession untrained. The remedy to this situation are increasingly being used in the form of, or professional development or In-service trainings (Bayar, 2014).

Different premeditated documents and researchers stress the need for continuous development of the proficiencies of teachers. For education sector the continuing professional development of teachers and their training is one of the fundamental development primacies. In the view of Ananiadou and Claro (2009), in-service teacher training or professional development is the vital constituent of any teacher education program. Due to the outburst of knowledge, teachers requisite to be equipping themselves to cope with the new challenges of teaching, learning are well as to upsurge to the international standards. In-service training and refresher courses are the mean to apprise the knowledge of the teacher and develop their skills and professional abilities in order to be able to satisfy the learner and demands of the modern teaching learning environment.

Professional development of teachers is essential to enhancing the eminence of education in educational institutes. Quality of education should vitally be assured of a high standard of preliminary education, training and continuing professional development of teachers. As with the fast going modern world and its modern professions, teachers are required to extend their professional knowledge horizons and equip themselves with high competitive teaching and assessment skills through systematic engagement in continuing professional development (CPD) and also through reflective practices. Both a high-quality preliminary training and a coherent and continuous in-service trainings are required in order to train teachers with the indispensable competences for their new roles. The system of in-service training should endow the most imperative opportunity for this to be attained (Kilfoye, 2015).

Wenglinsky's (2000) reported that if we want to improve education, we should give a primary concern to pre-service and in-service trainings in improving teacher quality. In employing teacher inputs, policy makers anticipated that there was a pragmatic connection between these inputs and the outputs of education and students' performance.

Teachers possess a vital state when it comes to liability for student accomplishment (Visser, Coenders, Terlouw, \& Pieters, 2013; and Penuel, Fishman, Yamaguchi, \& Gallagher, 2007). Therefore, it was established by Darling-Hammond, (2003) that competent teachers are significant for the improvement of eminence education. Likewise, Guskey (2009) highlighted this position of importance by observing that we cannot progress institutes without cultivating the skills and capacities of the instructors within them.

Dyer (2013) asserted that professional development opportunities support teachers in altering their behaviour in ways that affect student learning and achievement. The researchers agree that teacher quality and their professional development have a substantial impact on student accomplishment. Many studies investigating teacher quality and skills emphasis on the training of teachers in pre-service training programs. Studies show that often that there is lack appropriate preparation in the art of teachers for their allocated responsibilities and which need to be covered by in service trainings (Palardy \& Rumberger, 2008).

Professional development that enhances teachers' learning and their various teaching abilities has been revealed to be a crucial factor in enlightening the quality of schools as well as to be a factor in enhancing student's learning (Desimone, 2009).

Black and Wiliam (1998) pointed out in their article Inside the Black Box that the routine practice of classroom assessment is overwhelmed with shortcomings and so many problems. And as the teacher is 
the most important factor in students' learning so, a teacher who wants to practice formative assessment are requisite reconstruct their teaching contracts and also indulge in the activities to improve their assessment skills for formative use.

Plentiful evidence is there that teachers get benefited from the aptitude to interconnect with others in candid, open settings (Hamann \& Wunder, 2014; Zeichner, 2006; Tillema \& van der Westhuizen, 2006; and Shulman \& Shulman, 2004). The opportunity to participate in dialogue in a compassionate setting allows teachers to share their practices, to get to know about the latest advancement in the field of teaching, learning and hence, to become "living textbooks" (Rohlwing \& Spelman, 2014).

Snyder (2016) emphasized that operative professional development should also be constructed around the each teacher's needs, and required skills in order to be able to build their teaching around the diverse learning requirements of their students while implementing appropriately the classroom assessment practices. Research on professional development into upkeep teachers' formative assessment, understanding and practice faces the challenge of determining the efficacy of their implementation (Schneider \& Randel, 2009) particularly in terms of eminence instruction and student learning (Roeber, 2014).

Grounded on an investigation of teacher training policies in 25 countries, the OECD (2005) statement, lucidly entitled as "Teachers Matter" established that in an education system the quality of teacher is the most significant factor while, the second most principal factor (only preceded by family background) among the various of influences affecting student achievement. So teacher training and professional development should be a top most priority in any educational setting (Dorner \& Kárpáti, 2010).

\section{Professional Development of Teachers in Pakistan}

In Pakistan, mostly the efforts are made to train the teachers at secondary school level as well as the professional training is the prerequisite for all government school teaching. While so for the induction of teachers at University level is concerned, the professional training is not a prerequisite for getting the job there even lacking of systematic in-service teacher training at university level. Just few years back, Higher Education Commission (HEC) established a center for in-service faculty professional development with the name of "Learning Innovation Division (LID)". The purpose of which is to provide short and long duration training courses to the university teachers. As it is obvious without prerequisite professional training the newly appointed university teachers may not exhibit the instructional skills up to the desired level. In such cases in-service professional training and the opportunities to observe their senior trained colleagues are proving to be very productive in developing their pedagogical skills. It is important that the learning area for improvement must be identified by the teacher concerned and s/he should be provided professional support (Saleem, Masrur, \& Afzal, 2014).

This study concentrated on to explore the views of the university teachers for the need of refreshing trainings, particularly with respect to implementation of assessment practices for improving learning. This study emphases on the purpose of engendering expedient knowledge of teachers developing skills of assessment in order to institutional practices regarding assessment practices for cultivating learning. The study probes the significance of course trainings for developing of teachers' assessment skills in the KP public sector universities' under-graduate level programs. The main purpose of this study is to find out the significance of course trainings in developing assessment skills among teachers.

\section{Research Question}

The study was directed by the following research question:

i. What are the insights of teachers regarding the need for refreshing trainings in developing their skills to implement assessment for learning?

ii. How much teachers consider that refreshing trainings are helpful in the implementation of classroom assessment practices?

\section{METHODOLOGY}

A qualitative research approach was adopted for investigating teachers' perceptions of significance of refreshing trainings in developing teacher's assessment skills at undergraduate level in KhyberPakhtunkhwa. 


\section{Population, Sample Size and Its Distribution}

The population of this study was comprised of all the teachers of Public sector universities of Khyber Pakhtunkhwa out of which 40 teachers comprising both male and female were selected randomly from various disciplines of five public sector universities in KP.

\section{Data Collection Tool}

Semi-structured interview schedule was used to put up deep probes by the researcher for collection the relevant data from teachers. This approach permits responsiveness and suppleness to incipient issues for both interviewers and interviewees (Schwandt, 2001). Teachers were questioned for their insights concerning the necessity for refreshing trainings in enhancing their assessment skills.

\section{RESULTS AND ANALYSIS}

The results of the study are presented in the form Qualitative narratives to describe participants' perceptions on the significance and necessity of refreshing trainings for developing their assessment skills and implementation of those experiences of course trainings in the real classroom circumstances.

The following research queries are addressed in appraisal with, and discussion of these results.

\section{The Need of Refreshing Trainings for the Implementation of Classroom Assessment Practices}

When probed about the need for refreshing trainings, seminars and workshops etc. that's how ample they considered it substantially in the expansion of their skills for the implementation of classroom assessment practices. Almost all of teachers stressed the necessity of such refreshing trainings, seminars and workshops etc., however, very few of them has gone through such kind of trainings while most of them hadn't availed any such kind of opportunity at all. They share their insights and experiences in the following words while mostly reverberated with each other:

....such trainings or refreshing courses are of course, very essential as the purpose of those trainings is to build the capacity of teachers. They can be advantageous though, I haven't gone here in Pakistan from such activities but and I can say this from my experience during my stay in the United Kingdom for my PhD. so, over there they do train their post docs and PhD's faculty with the modern teaching methods, including various students centred assessment and learning techniques and particularly assessment practices were very much productive and according to the requirement of students learning. So, it could be constructive if some of those practices would be share amongst faculty members to get expand their skills and knowledge about assessment practices or any other teaching learning strategies. But, unfortunately it's my fifth year of teaching here and I hadn't get any such kind of opportunity till date. Besides, I haven't gone through any pre- service training nor in-service trainings formally and so I feel that I am lacking much of pedagogical skills which definitely are required to be improved and that could be possible though such types of trainings and workshops etc. as we are employed here on the bases of academic knowledge without having any professional teaching education. While, in the all of the developed countries the professional qualification is mandatory for the teachers' recruitment. So, in that case if here pre-service professional qualification is not required then there is highly need of in-service trainings after recruitment of faculty to develop their teaching skills and to fully train them in modern teaching learning and so assessment practices...

I am having much of difficulties in managing different activities though I get knowledge about latest assessment or learning activities but I think if we are provided with formal trainings opportunities then it will be convenient for us to overcome such hurdles which we do face while the management implementations of various new classroom assessment activities...

Earlier, I haven't ides about the importance of refresher trainings and courses but, once I had an opportunity to pass by a refreshing course and then I realised that such trainings are very supportive in cultivating and developing our professional skills, though it was not exactly about the classroom assessment techniques for learning and was regarding grading and evaluation procedures, statistics etc. but I got helped of that very much, so I do assert to be provided on regular bases all faculty with the new techniques whether in any field of teaching.....

....formal training are very important and such refresher courses should be arranged for faculty on regular basis as there are different skills which need to be developed and also modified with time and to know the international practices in the field of teaching and learning.

......As I mentioned that I was experienced in a school and then when join here in university I incorporate my those experiences in my teaching but not every teacher come here been passed through 
such experiences, so for them and also for even those who have some experiences need such type of trainings, refreshing courses and workshops etc. It is obvious that if you are provided with to some sort of trainings and give you some sort of opportunity to interact with fellow beings sharing that kind of approaches, so you can come up with a conclusion that what I should do to improve different teaching skills, you get to know new strategies and about your weak areas in teaching....

The above mentioned excerpts emphasized that refresher trainings and workshops are of utmost required to be provided to the faculty for the development of teaching skills along with to keep updating with the new techniques in the field of teaching and particularly assessment practices. Besides, there is need to train enough the teachers that to be able to implement various assessment practices in their own circumstances. It is also asserted by the research participants in order to facilitate teaching and learning we need to be keep equipped and to pace with the world in the teaching learning situation, it is essential to keep updated the teachers with modern assessment practices. And for that, they highlighted that preservice and in-service trainings of teachers must be channelized in a way to keep developing their professional skills throughout their career, and refreshing training and courses are a key element in this regard if provided regularly. The research participants further voiced on the assessment trainings experiences, they have gone through in the following way.

\section{The Experiences of Refreshing Trainings for the Implementation of Classroom Assessment Practices}

In accordance with their opinions about the suggested requirement for refresher trainings of assessment practices teachers were also probed to share their experiences about the trainings they have gone through with respect to assessment for learning and their usefulness in the implementation of assessment for learning. There was a response in negation by most of the research participants, particularly with respect to training with respect to the use of assessment practices for learning. Few of them shared their experiences of trainings they have gone through about other assessment practices and teaching learning strategies. They articulated, that such trainings have facilitated them in developing their capacity building, particularly in the applications of new techniques. Besides, such trainings helped them to develop their teaching skills in a way that have enabled them in managing classroom activities very well. However, while most of the participants replied impartially to this question, but few of them shared their experiences in the following utterances:

... we were given training about diverse assessment practices and their purposes for example, number-head together, use of portfolios, best use of think pair-share and jigsaw activity and some of other group activities...

....... learned much during such trainings, like a lot of things that how appropriately to engaged students in their learning process and so likewise to assess and do monitor their learning and different abilities through such assessment practices.

I had very good experiences and I got much about assessment practices which are better than the conventional practices of assessment through which it was hard to assess students' over-all development -...

...in getting participated in such trainings have changed my approaches to teaching and assessment have changed pretty enough. And now I can judge well and in a good position that for assessing a particular ability of students and their learning which type of assessment procedure will be more suitable and at what stage to be applied to monitor students learning timely. By using traditional approaches within classroom I have found always students as a passive listener's not active participant and mostly focused on the completion of the lengthy course without monitoring what they gaining but now by applying such assessment practices and knowing their worth in such trainings, I can best monitor my students learning and their strengths and weaknesses...

..I have gone through some of trainings not exactly about assessment for learning. Once, when I was teaching in Fauji foundation school there they provided us such trainings in our summer break and I learned much about different assessment strategies and few new assessment techniques, like peer assessment and portfolios but the training was not as such good means not in a practical way it was knowledge based but not got enough to skilled us to implement such practices in the real classroom environment. So in my view whenever the trainings are designed they should be in a manner that the participants not only get the knowledge but also get their skills developed. As knowledge can be taken now days from everywhere, but trainings mean to practically show to you about the strategies...

It is inferred that after getting trainings about the assessment practices, teachers found themselves skilled enough to assess their students' strengths and weaknesses and monitor their learning timely. Teachers also mentioned that they have found such assessment procedures more productive in improving students learning as compared to the traditional ways of assessment. Besides that, after 
having such trainings, teachers considered themselves in a better position to assess students' over-all development. Those participants who did not have any experience of such training, revealed their shortcomings in the assessment skills, and exposed their desire for the trainings to apprise their knowledge and skills in this regard:

Unfortunately, I haven't gone through any such trainings and experiences which may assist me in assessment practices. So mostly, relying on traditional assessments experiences which I do feel lacking much about assessing students strengths and weaknesses. Such trainings may support us in our professional development and will be able to provide good and competent services to achieve our objectives in the form of students successful learning as an outcome.

...... haven't taken any such kind of particular training or workshop and feel the lack in ability to incorporate new strategies so that's why feeling the thirst that to be given these kinds of opportunities in order be enabled to cope with the new needs of world and students. So the concerned departments for professional development of faculty should pay consideration to this in this regard and channelized continuous trainings for faculty development...

It is clear from the above discussion that teachers do welcome modern and ready to incorporate modern assessment practices. Research participants mentioned that they considered such refreshing trainings helpful and very effective for not only improving their knowledge and assessment skills, but also to make them enabled to develop their students' different skills and higher order learning abilities. They further highlighted that classroom assessment practices provide opportunities for grooming of different life skills to the students so for that purpose teachers must be highly equipped with such essential assessment skills to implement appropriately at classroom level. Research participants expressed their apprehension for not facilitating by in-service trainings and continuous refreshing courses which are vital for professional development and highlighted that concerned department should pay considerations for the professional development of faculty in this regard.

\section{DISCUSSION}

The analysis of data publicized that refreshing trainings and workshops are vital for the expansion of teachers' skills to get updated about the new techniques. Besides, to get trained enough in order to implement various classroom assessment practices in their own context. It is also asserted by the research participants that to keep aligned with the fast going world in the field of education and teaching, it is essential to keep restructured teachers with the modern assessment procedures to expedite learning through refreshing trainings regularly. The proposition was in mark with the result of the study by Saleem, Masrur and Afzal (2014) in which, the participants scored higher on the post-test as compared to their pre-test, presentation the enlightened effect of the training on the knowledge and skills of participants. This proposing that the refreshing trainings are operative for optimizing the efficacy of the programs for the professional development of faculty.

To stress the importance of teacher quality, the National Institute of Education in Singapore NIE (2009) recognized that students are required to accomplish new knowledge, skills and abilities to ensure their fortitude as individuals and as a productive member of the society and nation. To undertake this, we must progress teachers who are capable to embark greater errands as they are at the frontline and medium of enlightening our youth. Similarly, according to the Program for International Student Assessment (PISA) ratings for 2009, Singapore enumerated $5^{\text {th }}$, observing high enactment in learning outcomes. It was established by the educational decision makers in Singapore that to education quality the progress of teacher is the most determining factor.

The analysis of data also pointed out the high concerns by the teachers for not facilitating by inservice trainings and continuous refreshing courses which they considered very noteworthy for their professional development. Similarly, Al-Hattami, Muammar and Elmahdi, (2013) highlighted that in Pakistan the professional training for a university teacher is not the prerequisite and haven't no any systematic mechanism for in-service training for them as well. Likewise, the UCLA Survey (2005), Saudi universities antedates the Deanships for Academic Development through all the universities to provide trainings on diverse teaching skills to develop the capabilities of their faculty members. The study was resulted that there is highly need of training programs to promote faculty members' professional competencies in teaching.

\section{CONCLUSION}

The results of the study have brought to the surface the importance of the teacher refreshing trainings for the developing of teachers' teaching skills and student learning. It was concluded from the insights of the research participants that they welcome the modern assessment practices and deliberated its use very 
operative for not only improving students' learning but also for their overall development. High grievances were highlighted by the research participant for not facilitating in their professional development, particularly lack of in-service trainings and refreshing courses.

What seems palpable from the above discussion is that to keep equipped teachers of diverse teaching skills and also to cope with the contemporary essentials of time, training of teachers and their professional development is utmost indispensable.The researchers elevated that the Ministry of National Education must consider these verdicts and embark more effective and channelized professional development programs for teachers that to prepared their students in a way to strive in a 21st century global environment.

\section{RECOMMENDATIONS}

i. There may be proper planning for organizing and conducting refreshing trainings by educational ministries and institutions with respect to new classroom assessment practices.

ii. There may be channelized continuous in-service training's to 'expand teachers' professional skills.

iii. Additionally, to increase the awareness about the use of classroom assessment practices for learning in educational institutions, workshops, short-term courses, and seminars etc. should be organized to facilitate teachers for enhancing their level of competencies as well as to keep informed with the novel discoveries and inventions in the field of teaching and assessment practices.

\section{REFERENCES}

Airasian, P. W. (1994). Classroom assessment. New York: McGraw-Hill.

Al-Hattami, A., Muammar, O, and Ismail Elmahdi, I. (2013). The need for professional

training programs to improve faculty members teaching skills. EJRE published by International Association of Social Science Research - IASSR, European Journal of Research on Education, $1(2), 39-4$.

Ananiadou, K., \& Claro, M. (2009). 21st century skills and competences for new millennium learners in OECD countries. Assessment and accountability In: Phi Delta Kappan, 82, pp. 293-299.

Avalos, B. (2011). Teacher professional development in teaching and teacher education over ten years. Teaching and teacher education, 27(1), 10-20.

Bayar, A. (2014). The Components of Effective Professional Development Activities in Terms of Teachers' Perspective. Online Submission, 6(2), 319-327.

Beaton, A.E.; Postlethwaite, T.N.; Ross, K.N.; Spearritt, D.; Wolf, .M. (1999).The benefits and limitations of international educational achievement studies. Paris.

Bhatti, A., Pathan, H., Tabieh, A., \& Hassan, A., (2020). Impact of Learner-learner Rapport on L2 Learning: A Study of Public Sector Universities in Sindh, Pakistan. The Asian EFL Journal,27 (4.6), 204-226.

Black, P. J., and Wiliam, D. (1998). Inside the black box: Raising Standards Through

Classroom Assessment. Phi Delta Kappan, 80(2), 139-148.

Brookhart, S. M. (1999a). The art and science of classroom assessment: The missing part Of pedagogy. Washington, D.C.: ERIC Clearinghouse on Higher Education and Office of Educational Research and Improvement.

Brookhart, S. M. (1999b). Teaching about communicating assessment results and Grading. Educational Measurement: Issues and Practice, 18(1), 5-13.

Brookfield, Stephen D. (1995). Becoming a Critically Reflective Teacher. San Francisco: Jossey-Bass,

Burnstein, L.; Oakes, J.; Guiton, G. (1992). “Education indicators.” In: Alkin, M.C. (Ed.), Encyclopedia

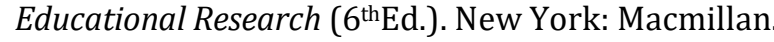

Carey, L. M. (1994). Measuring and evaluating school learning. Boston: Allyn and Bacon classroom assessment. Phi Delta Kappan, 80(2), 139-148.

Darling-Hammond, L. (2003). Keeping good teachers: Why it matters, what leaders can do? Educational leadership, 60(8), 6-13.

Darling-Hammond, L. \& Adamson, F. (2010). Beyond basic skills: The role of performance assessment in achieving 21st century standards of learning. Stanford, CA: Stanford University, Stanford Center for Opportunity Policy in Education.

Desimone, L. M. (2009). Improving impact studies of teachers' professional development: Toward better conceptualizations and measures. Educational researcher, 38(3), 181199. 
Derlina,, Aisyah,, Bukit, N., Sahyar,, Hassan, A., (2020). Blended Learning in English and English-Medium Physics Classes Using Augmented Reality, Edmodo, and Tinkercad Media. TESOL International Journal,15 (3), 111-136.

Dorner, H., \&Kárpáti, A. (2010). Mentoring for innovation: key factors affecting participant satisfaction in the process of collaborative knowledge construction in teacher training. Journal of Asynchronous Learning Networks, 14(4), 63-77.

Dudley-Marling, C., Abt-Perkins, D., Sato, K., \& Richard (Dickie) Selfe. (2006). Teacher $\quad$ quality: The perspectives of NCTE members. English Education, 167-193.

Dyer, K. (2013). The Case for Formative Assessment Teacher Professional Development. Retrieved on January, $6^{\text {th }}, 2018$, from, https://www.nwea.org/blog/2013/the-case-for formativeassessment-teacher-professional-development/education systems.

Washington DC: World Bank. Grading. Educational Measurement: Issues and Practice, 18(1), 5-13.

Griffin, P., \& Nix, P. (1991). Educational Assessment \& reporting: A new approach. Sydney: Harcourt Brace Jovanovich.

Guskey, T. R. (2000). Evaluating professional development. Corwin Press.

Guskey, T. R. (2009). Closing the knowledge gap on effective professional development. Educational horizons, 87(4), 224-233.

Hassan, A. (2016). Assimilation and incidental differences in Sindhi language. Eurasian Journal of Humanities, 2(1).

Hassan, A., Mitchell, R., \& Buriro, H. A. (2020). Changes in uses of salutations in British English. International research journal of management, IT and social sciences, 7(1), 197-204.

Hassan, A., Kazi, A.S., Shafqat, A., Ahmed, Z., (2020). The Impact of Process Writing on the Language and Attitude of Pakistani English Learners. The Asian EFL Journal,27 (4.3), 260-277.

Hassan, A. K. (2020, January). Semantic Complications in the War on Terror Discourse and Manipulation of Language by State and Non-State Actors. International research journal of management, IT and social sciences, 7, 162-168. doi: https://doi.org/10.21744/irjmis.v7n1.838

Hassan, A., N. D.-e.-A. (2015). Language planning and language policy dilemma in Pakistan. International Journal of Linguistics, Literature and Culture (Linqua- LLC), 2, No 4.

Hassan, A. (2017, April 9). Is Paninian grammar a Dependency grammar? Why or why not? DIMENSION Journal of Humanities and Social Sciences.

Human Resources Development (2009). Analysis of the Existing ETTA INSETT System and

Assessment of the needs for In-Service Training of Teachers IPA Component IV the European Union Program for Croatia Europe Aid/130730/D/SER/HR

Kilfoye, C. F. (2015). Making meaning of the new faculty majority: The growing ranks of contingent faculty in adult and continuing higher education. North-eastern University.

National Institute of Education (2009). A Teacher Education Model for the 21st Century: A Report by the National Institute of Education, Singapore. Retrieved on March, 21, 2018 from http://www.nie.edu.sg/files/spcs/Te21_online_ver.pdf.

Palardy, G. J., \& Rumberger, R. W. (2008). Teacher effectiveness in first grade: The importance of background qualifications, attitudes, and instructional practices for student learning. Educational evaluation and policy analysis, 30(2), 111-140.

Penuel, W. R., Fishman, B. J., Yamaguchi, R., \& Gallagher, L. P. (2007). What makes professional development effective? Strategies that foster curriculum implementation. American educational research journal, 44(4), 921-958.

Plake, B. S. (1993). Teacher assessment literacy: Teachers' competencies in the educational assessment of students. Mid-Western Educational Researcher, 6(1), 21-27.

Program for International Student Assessment (2009). Retrieved on March, 21, 2018 from http://www.pisa.oecd.org/document/61/0,3746,en_32252351_32235731_46

Race, P., Brown, S., \& Smith, B. (2004). 500 tips on assessment. Routledge. Reproduction Service No. 419838) results. Paper presented at the annual meeting of the National Council on performance assessment in achieving 21st century standards of learning. Stanford, Office of Educational Research and Improvement.

Roeber, E. (2014). Providing Professional Learning on Formative Assessment Methods for Educators.Washington, D.C.: ERIC Clearinghouse on Higher Education.

Saleem, A., Rehana M., R., Afzal, T. (2014). Effect of Professional Development on $\quad$ Enhancing the Knowledge Level of University Teachers in Pakistan. Journal of Research and Reflections in Education, 8 (2), pp162 -168.

Scheurich, J.J.; Skrla, L.; Johnson, J.E. (2000). "Thinking carefully about equity and accountability." In: Phi Delta Kappan, 82, pp. 293-299. 
Shah, M., H. (2000).The Impact of PEP-ILE inputs on Children's Achievement and Teacher's Behavior. PEP- GTZ. Abbott Abad.

Snyder, K. K. (2016). The Relationship of Formative Assessment to the Professional Development and Perspective Transformation of Teachers. The University of Nebraska-Lincoln.

Stiggins, R. J. (1992). High quality classroom assessment: What does it really mean? Educational Measurement: Issues and Practice, 11(2), 35-39.

Stiggins, R. J. (1997). Student-centered classroom assessment (2nd Ed.). Upper Saddle River, NJ: PrenticeHall.

Stiggins, R. J. (1999a). Are you assessment literate? The High School Journal, 6(5), 20-23.

Supriyatno, T., Susilawati, S., Hassan, A., (2020). E-learning development in improving students' critical thinking ability. Cypriot Journal of Educational Sciences, 15(5), 1099-1106. https://doi.org/10.18844/cjes.v15i5.5154.

Us Saqlain, N., Shafqat, A., Hassan, A., (2020). Perception Analysis of English Language Teachers about Use of Contextualized Text for Teaching ESP. The Asian ESP Journal,16 (5.1), 275-299.

Visser, T. C., Coenders, F. G., Terlouw, C., \& Pieters, J. (2013). Evaluating a professional development programme for implementation of a multidisciplinary science subject. Journal of education and training studies, 1(2), 89-102.

Wenglinsky, H. (2000). Educational Testing Service: Milken Family Foundation and Educational Testing Service. 